Kelaniya Journal of Human Resource Management

Volume 11, Number 02 - July 2016

DOI: http://doi.org/10.4038/kjhrm.v11i2.31

\title{
Impact of Work-Family Interface on Family Involvement in Business: A Review
}

\author{
Amali Ediriweera ${ }^{1}$, Anona Armstrong ${ }^{2}$ and Kumi Heenetigala ${ }^{3}$ \\ College of Law and Justice, Victoria University, Melbourne, Australia \\ ${ }^{1}$ amali.ediriweerra@live.vu.edu.au, ${ }^{2}$ Anona.armstrong@vu.edu.au, \\ ${ }^{3}$ Kumi.heenatigala@vu.edu.au
}

\begin{abstract}
This study aims at conducting a thorough literature review to explore and outline how business and family interface issues are tackled in family business research. A total of 76 family business articles with relation to workfamily interface were identified in the selected journals between year 2000 and 2014. Our study demonstrates that most of the studies give no information on the work-family interface. The articles were then categorized based on the identified 'research strategies' with different emphasis on business and family interface issues. The findings demonstrate the facets of work-family interface and their relevance into the family business, and its decision-making processes. It is argued that family business research needs theoretical upgrades by focusing primarily on work-family interface.
\end{abstract}

\section{Introduction}

Family businesses are the majority in most economies worldwide (Brice \& Richardson, 2009; Kwan, Lau, \& Au, 2012; Villalonga \& Amit, 2010). The two systems, business and family, often are inextricably linked (Danes \& Olson, 2003; Stafford, Duncan, Dane, \& Winter, 1999), and the patterns of interacting within the family often are unconsciously transferred to the business system (Danes \& Lee, 2004; Danes \& Olson, 2003; Hollander \& Bukowitz, 1990). Similarly, the work-family interface is no doubt a complicated issue, which, in turn, may have influences and implications for work-family fit (Rothausen, 2009) individual and business success, as well as national economic growth (Jennings \& McDougald, 2007; Kwan et al., 2012).

Recently, there has been a concern, emerging about the significance of workfamily interface with relation to family business (e.g.Eddleston \& Powell, 
2012; Rothausen, 2009). Moreover, there have been increasing calls to incorporate perspectives on work-family interaction into research on entrepreneurship, business ownership, and the relationship between business owners and firm performance (Barnett, Eddleston, \& Kellermanns, 2009; Jennings \& McDougald, 2007). Further, Rothausen (2009) claimed that family business researchers can benefit from knowledge of the primary findings of work-family researchers in management. However, apart from some exceptions work-family interface with relation to family business have only infrequently studied (Rothausen, 2009). Hence, there is a need for a thorough literature review to explore and outline how work-family interface aspects are tackled in family business research. Therefore this study focuses on reviewing how studies have reported work-family interface aspects with relevant to family business. We are also able to suggest gaps and areas for further research in the area.

\section{Methodology}

The research material is conducted by analyzing all articles with "family business" (or "family firm"), and "Work-family conflict" or "Work- family Enrichment" (or Facilitation, Positive spillover, Enhancement) or "Workfamily Balance" or "Work-family fit". The articles published in major journals, relating to entrepreneurship, family business and family were selected between year 2000 and 2014. The backward citation method was used with key words to select the journals with higher reference within selected terms. With this method, eight journals (Family Business Review, Entrepreneurship Theory and Practice, Journal of Business Venturing, International Small Business Journal, Journal of Family Business Strategy, Family Relations, Journal of Family and Economic Issues, Journal of family Issues) were identified. All the identified articles were screened in order to identify how work-family issues are tackled in family business research. This process resulted in 37 articles included at least some information on workfamily interface. In the analysis, how work-family interface variables have been addressed within family business research were recorded. The selection was backed by Chrisman, Chua, Kellermanns, Matherne, and Debicki (2008) who evaluated and ranked management journals as outlets for family business. 


\section{Findings}

In the following researchers discuss the findings of the screening and analysis based on the 37 articles identified and focus on variety of ways how workfamily interface is tackled in these studies. Categorisation of the studies is not exclusive and some studies are exemplary for a number of 'research strategies' are discussed below.

\subsection{Work-family interface}

Work-family interface experiences basically are two folds as Work-family conflict and work-family enrichment (Jennings \& McDougald, 2007; Powell $\&$ Greenhaus, 2006). However, work-family balance (Clarke, 2000; Shaffer, Joplin, \& Hsu, 2011; Voydanoff, 2002) and work-family fit (M. C. Clarke, Koch, \& Hill, 2004; Rothausen, 2009) too are included in work-family interface spheres. Three articles were found with key consideration to workfamily interface. Jennings, Breitkreuz, and James (2013) in their article of When Family Members Are Also Business Owners: Is Entrepreneurship Good for Families?, presented agenda for future research and under that they showed the directions for studies of work family integration by showing that there is considerable space for family scholars to contribute to the collective understanding of whether and how business ownership facilitates or detracts from work family integration. In the same year, Pieper, Astrachan, and Manners (2013) complemented work-family literature in family business field by incorporating conflicts caused by leadership or ownership roles that are not currently addressed in the literature, but may contribute to a more expanded understanding of the work-family interface. Furthermore Barnett et al. (2009) consistent with the work-family interface literature and the family embeddedness perspective, acknowledge the importance of workfamily issues in both family and nonfamily firms. In their article, they highlighted in literature that there are two basic views of family and career in the work-family literature as the conflict, or depletion perspective and enrichment, or enhancement perspective. Form these two views, the dominant view in literature is conflict view and enrichment view is less espoused (Greenhaus \& Powell, 2006). Not surprisingly, in this study too more studies with work-family conflicts and fewer studies with work-family enrichment were encountered. 
Findings were organised into main aspects of work family interface as workfamily conflict, work-family enrichment, work-family balance, and workfamily fit.

\subsection{Work-family conflict}

Work-family conflict is the most researched facet of work-family interface when compare to work-family enrichment and work-family balance. Workfamily conflict is defined by Greenhaus and Beutell (1985) as "[a] form of inter role conflict in which the role pressures from work and family domains are mutually incompatible in some respect". Work-family conflict arises when participation in the family role becomes difficult owing to the participation in work role and vice versa (Carlson, Kacmar, \& Williams, 2000). Accordingly, an empirical study by Boyar, Maertz, Pearson, and Keough (2003) showed that work-family conflict is driven by role conflict and role overload. Hence, work-family conflict reflects the integrity between work and family life.

Family firms offer possibilities for exploring unique patterns of work-family conflict dependencies not necessarily found in other work family situations(Karofsky et al., 2001). In a family business, work and family conflicts include issues that surface at the intersection of the family and the business subsystems (Boles, 1996). Fitzgerald, Winter, Miller, and Paul (2001) elaborate this further, stating that role conflict may be problematic for family members involved in family businesses because they struggle with expectations for the family role that conflict with the expectations of the business role. Supplementary to this, Danes and Lee (2004) provide an example of, when preschool-aged children are present in a family, the demands of caring for those young children and the demands from the family business can collide and lead to tensions. Work-family conflict is, however, potentially even more complex in family firms given the extended number of overlapping roles family managers can occupy in the family firm context (e.g., owner, manager, mother, sibling, daughter), making management of work-family conflict in family businesses a highly complex endeavour (Barnett et al., 2009). Thus work-family conflict could be rated as a key issue in family business that should be deep mined by practitioners and scholars in the field. 
In this study nineteen articles out of 37 with work-family conflict in family business were identified and they were categorised as "identified the concept and analysed" and "identified the concept but not analysed".

\subsection{Identified the concept and analysed}

Fourteen from nineteen articles have been identified work-family conflict as a major concern for the family business for its survival and success. Among them, in 6 studies, work-family conflict was a key variable in their analyses and in the rest, work-family conflict has been identified as significant predictor of success, succession and tension and as a result work-family conflict have been used in their models as a dimension or consequence of the main variables in their models.

\subsection{Work-family conflict as a main concern}

Karofsky et al., (2001) investigated work-family conflict and emotional wellbeing in American family businesses and presented important implications for family-work practices of business owners given that the ways in which people respond to work affect personal happiness, work effectiveness, and society. Added to that, their findings revealed that older owners report experiencing less work-household conflict and greater levels of workinterpersonal harmony. Business owners who work in the evenings and weekends, discuss business issues at home in the family, and conduct business activities at home experience more work-household conflict. As expected, these same owners also report experiencing less work-interpersonal harmony. The major implication from their study for business owners is that personal satisfaction and business accomplishments are intertwined in a family business. Another important study was conducted by Smyrnios et al. (2003). They focused on the interface and conflicts between work and family lives of business owners. From their empirical test of strain-based, workfamily conflict models on family businesses, they have come to a conclusion that work-interpersonal conflict is associated significantly and negatively with family cohesion, which in turn is related negatively to owners' reports of anxiety. Consequently, it confirmed the importance of specific mediating factors being associated with specific types of work-family conflict. 
Vera and Dean (2005) discussed about challenges face by daughter successors and identified work-family balance difficulties as one challenge. They fostered that achieving balance between work and family life was difficult, and managing their time between the business and the family is difficult. In addition they concluded that time required running the business takes daughter successors away from time with their husbands and/or children and social activities. Similar to this, Rothausen (2009) stated that individual family members in family businesses who have higher levels of responsibility for the emotional and physical care of dependent and nondependent family members and who are also highly involved in paid or unpaid work for the family business are more at risk for significant work family conflict, which in turn could decrease their human capital available to the business. On the other hand, Kwan et al. (2012) examined how type of businesses (family business vs. nonfamily business) moderates the relationships between familyto-work conflict and job satisfaction and social networks. They concluded that among family businesses, in comparison, owners' family-to-work conflict is not related to their job satisfaction and social networks. This study demonstrated that family-to-work conflict increases social networks and reduces job satisfaction for business owners and that being a family business moderates the effects of family-to-work conflict on job satisfaction and social networks.

Memili, Zellweger, and Fang (2013), studied the influence of family firm dynamics (i.e., family harmony and relationship conflict) on work-family conflict and family owner-managers' ownership attachment, which in turn impact affective organizational commitment. They introduced ownership attachment as an important antecedent to affective organizational commitment. Further they found that ownership attachment is positively affected by both family harmony and work-family conflict, whereby workfamily conflict is influenced by relationship conflict. They also found that work-family conflict affects ownership attachment. In the same year Shinnar, Cho, and Rogoff (2013) hypothesised that the relationship between family involvement in the business and owner's perception of family-business conflict is moderated by race/ethnicity and is stronger for African-American and Korean- American owned firms as compared to Mexican American and White-owned firms. Their findings indicated that family-business conflict 
management was a major problem for Korean-American entrepreneurs as compared to their White counterparts.

\subsection{Work-family conflict as a predictor}

Avery, Haynes, and Haynes (2000), Danes and Lee (2004), Danes and Olson (2003), and Gudmunson and Danes (2013) identified work-family conflict as a predictor of tension within family business. Along with Chronological order in 2000, Avery et al investigated level of tension between the family business and the household and work-family conflict were used to predict the tension. In 2003, Danes and Olson studied the involvement of the wife in the family business and described tensions over business issues based on the level of involvement of the wife in the business, and investigated the impact of business tensions on family business success. Work-family conflict was identified as one dimension of tension within family business. Further in 2004, Danes and Lee investigated business tensions of farm couples. They identified work-family conflict as one factor which creates tension within farm business-owning families. They came up with the findings as higher tensions were associated with more family financial resources being transferred to the business, having children under 5 years, husbands expressing the high importance of keeping the business in the family, and a high number of stressful events as experienced by the husband. Lower tensions were associated with husbands placing the family as a higher priority than business and reporting higher functional family integrity, and wives being more highly satisfied with their business roles. Again in 2013, Gudmunson and Danes identified work-family conflict as one factor which creates tension within farm business-owning families similar to Danes and Lee (2004) and Danes \& Olson (2003).

Another two studies were found in 2006 with relation to work-family conflict as one (Lee, 2006) was recoded which has examined the influence of family relationships on attitudes of the second generation working in their parents' family businesses. In this study four variables have been identified as consequences of work family conflicts but work-family conflict has not been directly measured or investigated. The other study was conducted by Zody, Sprenkle, MacDermid, and Schrank (2006). They investigated the connections between performance success and the boundaries between families and the businesses they own. They described work-family conflict 
as work-to-home negative spill-over and home-to-work negative spill-over and used it to measure the individual boundaries. Moreover, another work on work-family conflict was done by Cooper, Kidwell, and Eddleston (2013) in which they presented a model integrating family firm with family relations research. They explored potential difficulties experienced by family employees in making transitions from their family role to work role and the potential for family employees to engage in deviant behaviour due to unresolved conflict and ambiguity from work-family role integration. Workfamily conflict was identified as a cause of deviant behaviour in the family firm.

\subsection{Stated in literature review but not analysed}

Five articles are found with some conversation on work-family conflict in their literature review by showing that work-family conflict is worth to study pertinent to family business. Fitzgerald et al. (2001) mentioned in their literature review the importance of addressing work-family conflict when they investigate the roles that individuals perform that explain differences in the adoption of adjustment strategies by households with a family business. Danes, Rueter, Kwon, and Doherty (2002) cited that work-family conflict was a predictor of job satisfaction in family businesses, whereas for owners who did not work with family members, income was the predictor of job satisfaction. More over Dyer (2006) in his article written to provide an explanation for the contradictory evidence in the literature regarding the performance of family-owned firms, he pointed out previous research which had used work-family conflict/ interpersonal conflict as performance measures. Kirkwood (2009), by reviewing the literature, identified and acknowledged the significance of work-family conflict in family business and highlighted gaining support from a spouse prior to starting a business may lessen any work-family conflict that arises at a later date. Shepherd and Haynie too in 2009 proposed a process to manage identity conflict which is closely related with the behavioural aspects of work-family conflict. What they have highlighted in their article was, compartmentalization strategies used to manage work family conflicts are likely inadequate and inappropriate for family businesses as a mechanism to manage or avoid conflict resulting from the competing behavioral expectations of the family and business identities. As reasons for that they showed physical and temporal boundaries 
compartmentalisations are not practical in the case of family business and compartmentalization strategies preclude the family business from capitalizing on synergies between the two identities that may be important for the success of the family business.

\subsection{Work-family enrichment}

Concept that allows for the exploration of the potential positive outcomes of managing work and family roles is work-family enrichment (Hennessy, 2007). Work-family enrichment is a construct that represents how work and family roles can benefit one another and is defined as "the extent to which experiences in one role improve the quality of life in the other roles" (Greenhaus \& Powell, 2006). Further in line with Greenhaus and Powell (2006), Maertz and Boyar (2011) brought forwards the same view as engaging in more role commitment can provide more net benefit than less. More to the point Voydanoff (2004) defined as a form of synergy in which resources associated with one role enhance or make easier participation in the other role and more simply 'the extent to which participation in one role is made easier by virtue of the experiences, skills, and opportunities gained or developed in another role'. Work-family enrichment (Greenhaus \& Powell, 2006) is known as work-family facilitation(Grzywacz \& Butler, 2005; Shaffer et al., 2011; Voydanoff, 2005) or work-family enhancement (Voydanoff, 2002) or positive work-family spillover (Grzywacz, 2000; Grzywacz, Almeida, \& McDonald, 2002)

Similar to work-family conflict, work-family enrichment could originate from both work and family domains (Shaffer et al., 2011). Work experiences can improve the quality of one's family life i.e. work to family and family experiences can improve the quality of one's work life i.e. family to work. Family-to work enrichment has been found to be substantially stronger than work-to-family enrichment (Greenhaus \& Powell, 2006). Relative to workfamily conflict, work-family enrichment remains conceptually and empirically under-developed (Hennessy, 2007). This has been proved evidently in the field of family business too reporting less number of articles with comparison to work-family conflict though work-family enrichment could significantly affect the performance of family business and family members involved in the business. Only four articles were found with workfamily enrichment as a major concern and in one article (Ames, Brosi, \& 
Damiano-Teixeira, 2006) relevant to family business, they have acknowledged the Voydanoff (2004) statement about the need for a shift in research focus from work-family conflict to better understanding "work to family facilitation" which explained as the identification of factors that support better integration of work and family demands but not analysed or reported much.

\subsection{Work-family enrichment as a main concern}

Avery et al. (2000), investigated the decision to outsource child care among families involved in family-owned businesses. In their explanation about the level of tension between the family business and the household, they included the term facilitation instead of enrichment and under that family emotional support and household coordination, the degree to which the business encroaches on family life and vice versa were mentioned.

Rothausen (2009) stated that family leaders can consciously build support for work-family, which may in turn build familliness, by incorporating a broad set of criterion for measuring success that includes the well-being and development of all individuals in the family, including dependent members who may be elderly, children, or disabled. In addition, family leaders may influence who is considered a family business member (Distelberg \& Sorenson, 2009). Rothausen (2009) elaborated that if these leaders include employees' families as well as their own families as members of the system, family businesses have the potential to play a prominent role in the policy arena on work-family in business.

Eddleston and Powell (2012) examined how the family nurtures the entrepreneurial experience, particularly whether the processes by which the family nurtures work-family balance differ for female entrepreneurs as a group vis-à-vis male entrepreneurs as a group. To examine that they used positive facets of their family experiences, family-to-business enrichment, and support. The findings confirmed that satisfaction with work-family balance was nurtured by instrumental family-to business enrichment to the advantage of women as a group and by instrumental support from the family at home to the advantage of men as a group. Their interest lied with "familyto-business enrichment," which occurs when resources generated in the family domain are applied in the business domain in a way that benefits the 
business domain. More over in 2013, the work of Powell and Eddleston examined how experiences in family domain may benefit the experiences in business domain. It emphasised that affective family-to business enrichment, instrumental family-to-business enrichment, and family-to-business support would be positively related to entrepreneurial success and that each relationship would be more positive for female entrepreneurs than male entrepreneurs and this would apply to family businesses too.

\subsection{Work-family balance}

Greenhaus, Collins, and Shaw (2003) defined work-family balance as the extent to which an individual is equally engaged in - and equally satisfied with - his or her work role and family role. Further they identified the possibility of positive and negative balance in their definition of work-family balance. According to them, positive balance suggests an equally high level of satisfaction with work and non-work roles while negative balance implies an equally low level of satisfaction with those roles. Their definition has three components that include time balance, involvement balance and satisfaction balance. They conceptualize balance as independent of an individual's desires or values, which is consistent with the idea of Clark (2000). In her work and family border theory, Clark (2000) argues that people can shape the nature of work and life to some degree to create a desired balance because individuals are border-crossers. It is clear that the "right" balance is a very personal thing; no easy or quick fixes can be found and there are no "one size fits all" solutions (Lewis, Rapoport, \& Gambles, 2003). The existing literature of work-family balance has acknowledged the degree of its inconsistency. Pocock (2005) viewed that workers who are satisfied with their work-family balance are likely to be happier social citizens, parents, carers and more productive workers. They may work longer and more productively over their lives, making a greater public contribution, and their health, along with the health of their dependants and partners, may be better, reducing public health expenditure and generally increasing social wellbeing. The same could be applied to family business owners and family members working in family businesses. 


\subsection{Work-family balance as a main concern}

Two articles were found with work-family balance as a major concern. Gudmunson, Danes, Werbel, and Loy (2009) examines whether emotional spousal support contributes to business owners' perceived work family balance while launching a family business and came up with findings of that business owner work hours have an additive negative effect on work-family balance. Thus, business-related spousal support may at times threaten workfamily balance because it takes energy in the form of time and personal attention to participate in social interactions. However, they claimed that satisfying communication about core business issues as business objectives, strategy, and finances creates regenerative power that fuels work-family balance. Elaborating further, they explained that targeted business communication with the spouse creates an energy resource gain for the business owner. On the other hand they concluded that the business owner's work hours also had an additive negative effect on the work-family balance of the business owner. Thus, multiple means exist for maintaining workfamily balance, and the effects of work related social support are dependent on context.

Helmle, Botero, and Seibold (2014) who explored the factors that influence perceptions of work-family balance among owners of copreneurial firms, offered some implications for family firms and co-founded ventures. They argued that copreneurial firms as a unique type of family firm which has the potential to shed light on the differences between family firms. Their results indicated that work family conflict and spousal support are directly related to perceptions of work-family balance in these copreneurial firms. At the same time, job involvement, flexibility at work, and permeability of communication at home were significantly related to work to family conflict. Although communication about work at home and permeability of communication were significantly related to family to work conflict, this type of conflict could not influence perceptions of work-family balance. They believed that their study provides an initial nomological network for understanding the predictors of work-family balance, and that the findings shed light on how work, family, and communication factors play a role in perceptions of work and life domains in the context of copreneurial firms and possibly family firms in general. 


\subsection{Work-family balance as a main goal}

Philbrick and Fitzgerald (2007) compared groups of women associated with family businesses and ascertain predictors of functionality. In this study they identified work-family balance as an important long-range goal for family and included in their measures of the study.

\subsection{Stated in literature review but not analysed}

Three articles found with evidence on work-family balance in their literature reviews. The first is Lee, Danes, and Shelley (2006). This article highlighted the importance of having work-family balance and stressed the effects of work family conflict. And this article has been done to find out the relationship between management activity of married women within family businesses and perceived well-being controlling for work roles, family context, personal and financial resources. The next by Distelberg and Blow (2010) discussed the literature about work-family balance field which has explored the validity of an ecosystems perspective (Seery, Corrigall, \& Harpel, 2008; Son \& Bauer, 2010; Voydanoff, 2002) and found validity in viewing this family-work balance issues through the lens of ecosystems. The final by Brewton, Danes, Stafford, and Haynes (2010) agreed with that the negative relationship between crossover of family and business tasks and resilience for rural firms. This suggests that if a rural manager's pattern of work-family balance crosses system boundaries so that family tasks are completed at the firm or firm tasks are completed at home, resilience could be reduced at the time of a disaster. Balance will likely be lost because demands in both systems tend to be high following natural disasters and usual patterns of work-family balance may no longer be effective for them.

\subsection{Work-family fit}

Work-family fit has recently emerged in work and family literature, comparable to work-family balance in that it represents interactions between work and family and yet distinct because it precedes balance and other outcomes (Clarke et al., 2004). More to the point, Clarke et al describe fit as the relationship between the demands placed on people and their efforts to meet those demands. Thus those who experience conflict and report balance and those who experience conflict and report imbalance is one's sense of 
work-family fit (Clarke et al., 2004; Voydanoff, 2002, 2005). However, Grzywacz and Bass (2003) stated that work-family fit as the combination of work-family conflict and work family enrichment. Still, the concept of fit is in its theoretical stages, as there are relatively few studies testing the chain of work-family demands, interactions, fit, and outcomes (Voydanoff, 2002). Turning to family business studies only one study was found with workfamily fit. That is Rothausen (2009) "Management Work-Family Research and Work-Family Fit; Implications for Building Family Capital in Family Business" In her work explained "Improving work-family fit for family members will likely facilitate the inclusion of more family members in both the family and the business domains, which in turn would increase family human capital (knowledge, technical abilities, emotional strength, intellectual capital, and family social capital); cohesiveness; shared goals and vision; strength, quality, and intensity of social ties; and identification with the family and the family business".

\subsection{Women, work family interface, and family business}

When work-family was first identified as an area of research, it was characterized as a women's issue and an individual-level issue both in organizations and management research (Rothausen, 2009). Similar to that in family business field too consideration towards women could be seen. Lee et al. (2006) situated that married women who work in business-owning families may be different from married women in typical dual-earner families because they face constraints and barriers at the interface of the business and family systems. Family businesses that explicitly address work family conflict thus promote the fuller inclusion of these family members who are more likely to be women in the business (Rothausen, 2009). Thus, the existence of role conflict for women in family businesses is documented. For example, Danes and Lee (2004) claimed that there were differences between wives and husbands in their reports of tensions from conflicts related to issues of justice, identity, and work and family. As expected, wives reported more tensions. Danes and Olson (2003) conveyed that wives reported higher tension and business and family success outcomes varied by level of tensions. In addition, with regard to work-family enrichment, Eddleston and Powell (2012) suggested that the processes by which the family nurtures the workfamily balance of entrepreneurs differ according to entrepreneur sex. Women 
as a group appear to nurture their satisfaction with work-family balance by creating instrumental enrichment between their family and business roles, whereas men as a group appear to nurture their satisfaction with work-family balance by drawing upon instrumental support in the home. Also Philbrick and Fitzgerald (2007) compared groups of women associated with family businesses and ascertain predictors of functionality. Hence they advocate that family therapists and family business consultants must be cognizant of the multiple role responsibilities of women associated with a family firm. More to the point Powell and Eddleston (2013) too offered substantial support for the notion that female entrepreneurs benefit from the linkages of family-tobusiness enrichment and support to entrepreneurial success, whereas they offered no support for the notion that male entrepreneurs benefit from these linkages. Female entrepreneurs may experience such benefits because of their relative lack of access to other resources such as human, social, and financial capital and because the female gender role encourages them to pursue workfamily synergies. Consequently in terms of women in family business field consistency with the literature on work-family balance could be identified with the above evidence.

\section{Discussion and Conclusion}

Yet researchers, practitioners, and therapists lack a good understanding of the significant impact these businesses and ventures have on the families who own and operate them, an area of research that implicitly addresses this phenomenon is the literature on the work-family interface (Pieper et al., 2013). The contribution of the study is to demonstrate how work-family interface is included in family business studies. We identify that less number of studies provide information on the work-family interface. The minority of the studies addressing work-family interface either explicitly or implicitly are informative on the different strategies applied in the family business research. The most researched construct of work-family interface in family business field is work-family conflict (Karofsky et al., 2001;Kwan et al., 2012; Smyrnios et al., 2003). Work-family conflict is mainly addressed comparative to the other construct in work-family interface in different ways. Some studies apply work-family conflict more thoroughly and include work-family conflict in the analytical framework and discuss the hypothesized differences accordingly while other studies only mentioned about it in their literature 
review or discussion sections. Hence, researchers were able identified them as "identified the concept of work-family interface and analysed" and" stated in literature review but not analysed". The studies which have identified the concept of work-family interface and analysed visibly is two folds as workfamily conflict as a main concern and work-family conflict as an antecedent since some studies explore work-family conflict including it into their research model as a main variable and other studies have addressed it as an antecedent of tension.

Even though work family scholars have the potential to integrate research in economics, sociology, and psychology and so help form interdisciplinary teams to conduct research on family businesses (Stafford \& Tews, 2009), only a few studies explore the other construct of work-family interface in the context of wider social forces. Not different to the work-family interface as a field itself, in family business too work-family conflict was understood with the role of women with conclusion that work-family conflict is higher for women (Lee et al., 2006). Findings supported the Rothausen's (2009) claim of two empirical studies (Karofsky et al., 2001; Smyrnios et al., 2003) in the family business literature suggests that work-family conflict models also fit individuals in family businesses.

It is argued that family business research needs theory developments with work-family interface to better explain hoe family businesses performs. However, still in family business field less focus on work-family interface construct and even that focus is also mainly on work-family conflict solely could be seen. Very few studies were found with work-family enrichment, work-family balance and work-family fit. Although one of the earliest criteria for a healthy family business is that of balance between the family and the business (Distelberg \& Sorenson, 2009)), there has been limited empirical research focusing on how well members of business-owning families balance competing demands between work and the family (Stafford \& Tews, 2009). Interestingly only Rothausen (2009) addressed the notion of work-family fit in family business field. Therefore having interest primarily only on one construct of work-family interface uncover the part of the total dialogue. To achieve better outcomes, to explore how family component integrate in in family business, at least two different constructs in work-family interface (e.g. work-family conflict and work-family enrichment) should be included 
in a model developed to analyse family involvement into business or family business success.

The field of family firm research has long strived to create an overall theory of the family firm (e.g.Chrisman, Chua, \& Sharma, 2005; Chua, Chrisman, $\&$ Steier, 2003), and such a theory will remain incomplete without an explicit incorporation of the family relations element of the family firm (Morris \& Kellermanns, 2013). Therefore, further studies are suggested to focus on capturing also empirically "the family" which has been conceptualized as focal in family business research. More importantly our study demonstrates the need to investigate the complex mechanisms of family and business with special focus on work-family interface. Addressing these gaps requires a thorough methodological re-thinking in order to tackle the challenge of linking not only work-family conflict but also the other construct in workfamily interface with family business for the betterment of the field. For instance Stafford and Tews (2009) revealed that one of the most promising aspects of work family balance scholarship for family businesses is its potential to bridge disciplines to advance empirical research on how to tell whether overlaps between a family and its business are congruent with their healthy functioning. There is also the opportunity to compare work-family balance in family and nonfamily businesses and to compare family balance strategies with organizational programs (Stafford \& Tews, 2009). This study has mainly focused on how work-family interface is being studied in family business research, but it would be equally interesting to find out what are the themes that are more likely to be tackled with the standpoint of work-family interface.

\section{References}

Ames, B. D., Brosi, W. A., \& Damiano-Teixeira, K. M. (2006). "I'm Just Glad My Three Jobs Could Be During the Day": Women and Work in a Rural Community. Family Relations, 55(1), 119-131.

Avery, R. J., Haynes, D. C., \& Haynes, G. W. (2000). Managing Work and Family: The Decision to Outsource Child Care in Families Engaged in FamilyOwned Businesses. Journal of Family and Economic Issues, 21(3), 227-258.

Barnett, T., Eddleston, K., \& Kellermanns, F. W. (2009). The Effects of Family Versus Career Role Salience on the Performance of Family and Nonfamily Firms. Family Business Review, 22(1), 39-52. 
Boles, J. S. (1996). Influences of Work-Family Conflict on Job Satisfaction, Life Satisfaction and Quitting Intentions Among Business Owners: The Case of Family-Operated Businesses. Family Business Review, 9(1), 61-74.

Boyar, S. L., Maertz, C. P., Pearson, A. W., \& Keough, S. (2003). Work-Family Conflict: A Model Of Linkages Between Work And Family Domain Variables And Turnover Intentions. Journal of Managerial Issues, 15(2), 175-190.

Brewton, K. E., Danes, S. M., Stafford, K., \& Haynes, G. W. (2010). Determinants of rural and urban family firm resilience. Journal of Family Business Strategy, 1, 155-166.

Brice, W. D., \& Richardson, J. (2009). Culture in family business: a two-country empirical investigation. European Business Review, 21(3), 246-262.

Carlson, D. S., Kacmar, K. M., \& Williams, L. J. (2000). Construction and Initial Validation of a Multidimensional Measure of Work-Family Conflict. Journal of Vocational Behavior, 56, 249-270.

Chrisman, J. J., Chua, J. H., Kellermanns, F. W., Matherne, C. F., \& Debicki, B. J. (2008). Management Journals as Venues for Publication of Family Business Research. Entrepreneurship Theory and Practice, 32(5), 927-934.

Chrisman, J. J., Chua, J. H., \& Sharma, P. (2005). Trends and Directions in the Development of a Strategic Management Theory of the Family Firm. Entrepreneurship Theory and Practice, 29, 555-575.

Chua, J. H., Chrisman, J. J., \& Steier, L. P. (2003). Extending the Theoretical Horizons of Family Business Research. Entrepreneurship Theory and Practice, 27(4), 331-338.

Clarke, M. C., Koch, L. C., \& Hill, E. J. (2004). The Work-Family Interface: Differentiating Balance and Fit. Family and Consumer Sciences Research Journal, 33(2), 121-140.

Clarke, S. C. (2000). Work/family border theory: A new theory of work/family balance. Human relations, 53(6), 747-770.

Cooper, J. T., Kidwell, R. E., \& Eddleston, K. A. (2013). Boss and Parent, Employee and Child: Work-Family Roles and Deviant Behavior in the Family Firm. Human relations, 62, $457-471$.

Danes, S. M., \& Lee, Y. G. (2004). Tensions Generated by Business Issues in Farm Business-Owning Couples. Family Relations, 53(4), 357-366. 
Danes, S. M., \& Olson, P. D. (2003). Women's Role Involvement in Family Businesses, Business Tensions, and Business Success. Family Business Review, 16(1), 53-68.

Danes, S. M., Rueter, M. A., Kwon, H.-K., \& Doherty, W. (2002). Family FIRO Model: An Application to Family Business. Family Business Review, 15(1), 31-43.

Distelberg, B., \& Blow, A. (2010). The Role of Values and Unity in Family Businesses. Journal of Family and Economic Issues, 31, 427-441.

Distelberg, B., \& Sorenson, R. L. (2009). Updating Systems Concepts in Family Businesses: A Focus on Values, Resource Flows, and Adaptability. Family Business Review, 22(1), 65-81.

Dyer, W. G. (2006). Examining the "Family Effect" on Firm Performance. Family Business Review, 19(4), 253-273.

Eddleston, K. A., \& Powell, G. N. (2012). Nurturing Entrepreneurs' Work-Family Balance: A Gendered Perspective. Entrepreneurship Theory and Practice, 36(3), 513-541.

Fitzgerald, M. A., Winter, M., Miller, N. J., \& Paul, J. (2001). Adjustment Strategies in the Family Business: Implications of Gender and Management Role. Journal of Family and Economic Issues, 22(3), 265-291.

Greenhaus, J. H., \& Beutell, N. J. (1985). Sources of Conflict between Work and Family Roles. The Academy of Management Review, 10(1), 76-88.

Greenhaus, J. H., Collins, K. M., \& Shaw, J. D. (2003). The relation between workfamily balance and quality of life. Journal of Vocational Behavior, 63, 510531.

Greenhaus, J. H., \& Powell, G. N. (2006). When Work and Family Are Allies: A Theory of Work-Family Enrichment. The Academy of Management Review, 31(1), 72-92.

Grzywacz, J. G. (2000). Work-family spillover and health during midlife: is managing conflict everything? American Journal of Health Promotion, 14(4), 236-243.

Grzywacz, J. G., Almeida, D. M., \& McDonald, D. A. (2002). Work-Family Spillover and Daily Reports of Work and Family Stress in the Adult Labor Force. Family Relations, 51, 28-36. 
Grzywacz, J. G., \& Bass, B. L. (2003). Work, Family, and Mental Health: Testing Different Models of Work-Family Fit. Journal of Marriage and Family, 65(1), 248-261.

Grzywacz, J. G., \& Butler, A. B. (2005). The Impact of Job Characteristics on

Work-to-Family Facilitation: Testing a Theory and Distinguishing a Construct. Journal of Occupational Health Psychology, 10(2), 97-109.

Gudmunson, C. G., \& Danes, S. M. (2013). Family Social Capital in Family Businesses: A Stocks and Flows Investigation Human relations, 62, 399 414.

Gudmunson, C. G., Danes, S. M., Werbel, J. D., \& Loy, J. T.-C. (2009). Spousal Support and Work-Family Balance in Launching a Family Business. Journal of Family Issues, 30(8), 1098-1121.

Helmle, J. R., Botero, I. C., \& Seibold, D. R. (2014). Factors that influence perceptions of work-life balance in owners of copreneurial firms. Journal of Family Business Management, 4(2), 110-132.

Hennessy, K. D. (2007). Work-Family Balance: An Exploration of Conflict and Enrichment for Women in A Traditional Occupation. (Doctor of Philosophy), University of Maryland, College Park.

Hollander, B. S., \& Bukowitz, W. R. (1990). Women, Family Culture, and Family Business. Family Business Review, 3(2), 139-151.

Jennings, J. E., Breitkreuz, R. S., \& James, A. E. (2013). When Family Members Are Also Business Owners: Is Entrepreneurship Good for Families? Human relations, 62, 472-489.

Jennings, J. E., \& McDougald, M. S. (2007). Work-Family Interface Experiences and Coping Strategies: Implications for Entrepreneurship Research and Practice. The Academy of Management Review, 32(3), 747-760.

Karofsky, P., Millen, R., Yilmaz, M. R., Smyrnios, K. X., Tanewski, G. A., \& Romano, C. A. (2001). Work-Family Conflict and Emotional Well-Being in American Family Businesses. Family Business Review, 14(4), 313-324.

Kirkwood, J. (2009). Spousal Roles on Motivations for Entrepreneurship: A Qualitative Study in New Zealand. Journal of Family and Economic Issues, 30, 372-385.

Kwan, H. K., Lau, V. P., \& Au, K. (2012). Effects of Family-to-Work Conflict on Business Owners: The Role of Family Business ) Family Business Review Family Business Review, 25(2), 178-190. 
Kelaniya Journal of Human Resource Management Volume 11, Number 02 - July 2016

Lee, J. (2006). Impact of Family Relationships on Attitudes of the Second Generation in Family Business. Family Business Review, 19(3), 175-191.

Lee, Y. G., Danes, S. M., \& Shelley, M. C. (2006). Work Roles, Management and Perceived Well-being for Married Women within Family Businesses. Journal of Family and Economic Issues, 27, 523-541.

Lewis, S., Rapoport, R., \& Gambles, R. (2003). Reflections on the integration of paid work and the rest of life. Journal of Managerial Psychology, 18(8), 824-841.

Maertz, C. P., \& Boyar, S. L. (2011). Work-Family Conflict, Enrichment, and Balance under "Levels" and "Episodes" Approaches. Journal of Management, 37(1), 68-98.

Memili, E., Zellweger, T. M., \& Fang, H. C. (2013). The Determinants of Family Owner-Managers' Affective Organizational Commitment. Human relations, $62,443-456$.

Morris, M. L., \& Kellermanns, F. W. (2013). Family Relations and Family Businesses: A Note From the Guest Editors. Family Relations, 62, 379 383.

Philbrick, C. A., \& Fitzgerald, M. A. (2007). Women in Business-owning Families: a Comparison of Roles, Responsibilities and Predictors of Family Functionality. Journal of Family and Economic Issues, 28, 618-634.

Pieper, T. M., Astrachan, J. H., \& Manners, G. E. (2013). Conflict in Family Business: Common Metaphors and Suggestions for Intervention. Family Relations, 62, 490-500.

Pocock, B. (2005). Work-life 'balance' in Australia: Limited progress, dim prospects. Asia Pacific Journal of Human Resources, 43(2), 198-209.

Powell, G. N., \& Eddleston, K. A. (2013). Linking family-to-business enrichment and support to entrepreneurial success: Do female and male entrepreneurs experience different outcomes? Journal of Business Venturing, 28, 261-280.

Powell, G. N., \& Greenhaus, J. H. (2006). Is the opposite of positive negative?: Untangling the complex relationship between work-family enrichment and conflict. Career Development International, 11(7), 650-659.

Rothausen, T. J. (2009). Management Work-Family Research and Work-Family Fit: Implications for Building Family Capital in Family Business. Family Business Review, 22(3), 220-234. 
Seery, B. L., Corrigall, E. A., \& Harpel, T. (2008). Job-Related Emotional Labor and Its Relationship to Work-Family Conflict and Facilitation. Journal of Family and Economic Issues, 29, 461-477.

Shaffer, M. A., Joplin, J. R. W., \& Hsu, Y.-S. (2011). Expanding the boundaries of work-family research: A review and agenda for future research. International Journal of Cross Cultural Management, 11(2), 221-268.

Shepherd, D., \& Haynie, J. M. (2009). Family Business, Identity Conflict, and an Expedited Entrepreneurial Process: A Process of Resolving Identity Conflict. Entrepreneurship Theory and Journal, 33, 1245-1264.

Shinnar, R. S., Cho, S., \& Rogoff, E. G. (2013). Outcomes of family involvement in minority owned family businesses. Journal of Family Business Strategy, 4, 22-33.

Smyrnios, K. X., Romano, C. A., Tanewski, G. A., Karofsky, P. I., Millen, R., \& Yilmaz, M. R. (2003). Work-Family Conflict: A Study of American and Australian Family Businesses. Family Business Review, 16(1), 35-51.

Son, S., \& Bauer, J. W. (2010). Employed Rural, Low-Income, Single Mothers' Family and Work Over Time. Journal of Family and Economic Issues, 31, 107-120.

Stafford, K., Duncan, K. A., Dane, S., \& Winter, M. (1999). A Research Model of Sustainable Family Businesses. Family Business Review, 12(3), 197-208.

Stafford, K., \& Tews, M. J. (2009). Enhancing Work-Family Balance Research in Family Businesses. Family Business Review, 22(3), 235-238.

Vera, C. F., \& Dean, M. A. (2005). An Examination of the Challenges Daughters Face in Family Business Succession. Family Business Review, 18(4), 321345 .

Villalonga, B., \& Amit, R. (2010). Family Control of Firms and Industries. Financial Management, 39(3), 863-904.

Voydanoff, P. (2002). Linkages Between the Work-family Interface and Work, Family, and Individual Outcomes: An Integrative Model. Journal of Family Issues, 23, 138-164.

Voydanoff, P. (2004). The Effects of Work Demands and Resources on Work-toFamily Conflict and Facilitation. Journal of Marriage and Family, 66, 398412. 
Kelaniya Journal of Human Resource Management

Volume 11, Number 02 - July 2016

Voydanoff, P. (2005). Toward a Conceptualization of Perceived Work-Family Fit and Balance: A Demands and Resources Approach. Journal of Marriage and Family, 67(4), 822-836.

Zody, Z., Sprenkle, D., MacDermid, S., \& Schrank, H. (2006). Boundaries and the Functioning of Family and Business Systems. Journal of Family and Economic Issues, 27(2), 185-206. 